\title{
Localization of BDNF mRNA with the Huntington's disease protein in rat brain
}

\author{
Bin Ma ${ }^{1}$, Brady P Culver ${ }^{1}$, Gabriele Baj ${ }^{2}$, Enrico Tongiorgi ${ }^{2}$, Moses V Chao ${ }^{3}$, Naoko Tanese ${ }^{1 *}$
}

\begin{abstract}
Background: Studies have implicated reduced levels of brain-derived neurotrophic factor (BDNF) in the pathogenesis of Huntington's disease. Mutant huntingtin (Htt) protein was previously reported to decrease BDNF gene transcription and axonal transport of BDNF. We recently showed that wild-type $\mathrm{Htt}$ is associated with the Argonaute 2 microRNA-processing enzyme involved in gene silencing. In dendrites, Htt co-localizes with components of neuronal granules and mRNAs, indicating that it might play a role in post-transcriptional processing/transport of dendritic mRNAs.
\end{abstract}

Results: We conducted imaging experiments in cultured cortical neurons to demonstrate the co-localization of endogenous Htt and BDNF mRNA in fixed cells, and co-trafficking of BDNF 3'UTR mRNA with endogenous and fluorescently tagged $\mathrm{Htt}$ in live neurons. We used an enhanced technique that combines FISH and immunofluorescent staining to co-localize BDNF mRNA with Htt, Ago2, CPEB and dynein in thick vibratome sections of the rat cortex.

Conclusions: In cultured neurons and sections of the rat cortex, we found BDNF mRNA associated with Htt and components of neuronal RNA granules, which are centers for regulating RNA transport and local translation. Htt may play a role in post-transcriptional transport/targeting of mRNA for BDNF, thus contributing to neurotrophic support and neuron survival.

\section{Background}

Huntington's disease (HD) protein huntingtin (Htt) is a $350 \mathrm{kDa}$ protein widely expressed at high levels in the hippocampus, cortex, cerebellum and striatum. Expansion of a triplet CAG repeat sequence in the 5' end of the $\mathrm{Htt}$ gene generates a protein with poly-glutamine repeat expansion, which is the cause of HD, an autosomal dominant neurodegenerative disorder characterized by uncontrolled movements, personality changes, dementia and death [reviewed in [1,2]]. Although the pathogenesis of HD involves many processes, current evidence suggests significant dysfunction of neurons leading to progressive neuronal loss initially in the striatum. The ubiquitous expression of $\mathrm{Htt}$ does not provide an explanation for the selective striatal cell neurodegeneration at the onset of HD. Wild-type Htt has been implicated in many cellular functions including regulation of gene expression, endocytosis and microtubule-

\footnotetext{
* Correspondence: tanesn01@med.nyu.edu

'Department of Microbiology, New York University School of Medicine, New York, NY 10016, USA
}

directed vesicular trafficking in axons and dendrites [reviewed in [3]]. Several studies have linked brainderived neurotrophic factor (BDNF) with HD [reviewed in [4]], and hence, it is a possible therapeutic target for the disease [5,6]. Transcription of BDNF is reported deregulated in $\mathrm{HD}$, and transport of BDNF secretory vesicles necessary for neuronal survival requires a functional $\mathrm{Htt}[7,8]$.

Recently, we have localized Htt with the small RNAassociated protein Argonaute 2 (Ago2) in processing (P)-bodies from somatic cells [9], and in neuronal RNA granules involved in transport and local translation of mRNA in dendrites [10]. Because Ago2 has specific roles in RNA processing and gene silencing in restricted domains of the cell, the association with Htt in ribonucleoprotein particles (P-bodies and neuronal granules) provides a possible mechanism to account for the transport and translation of specific mRNAs. There are many potential genes that may be controlled at a posttranscriptional level by Ago2 and Htt. Because multiple isoforms of BDNF mRNA are transported to dendrites 
$[11,12]$, we hypothesized that $\mathrm{Htt}$, in association with Ago2, might regulate BDNF mRNA processing and/or trafficking.

\section{Results \\ Huntingtin co-localizes with BDNF mRNA in cortical neurons}

We recently reported that Htt associates with components of neuronal RNA granules and contributes to transport of mRNA in dendrites [10]. Purification of endogenous $\mathrm{Htt}$ from mouse brain extracts demonstrated presence of Ago2 protein as well as brain-specific mRNAs such as $\mathrm{IP}_{3} \mathrm{R} 1$, CaMKII $\alpha$ and MAP2. The BDNF gene encodes for multiple alternatively spliced transcripts that target different dendritic compartments [13]. Significantly, the G196A mutation in the BDNF gene associated with neuropsychiatric disorders was found to block dendritic targeting by altering the binding site for the RNA binding protein translin which mediates dendritic targeting [13]. Because BDNF levels are reduced in the brains of HD patients and HD mouse models, we sought to investigate whether Htt might be involved in the transport of BDNF mRNA through neuronal RNA granules.

To localize Htt and BDNF mRNA, rat cortical neurons (DIV 8) were stained for endogenous Htt with an antibody to Htt (MAB2166, Millipore). The specificity of the antibody was first determined by western blotting of mouse brain fractions prepared by sequential centrifugation of total brain homogenate (see Methods). Probing with MAB2166 demonstrated highly specific and broad subcellular distribution of endogenous full-length Htt (Fig. 1a). Furthermore, knockdown of Htt by shRNA resulted in loss of the immunoreactive band, and reduced immunostaining of Htt in cortical neurons [10]. Htt-/- ES cells showed no detectable immunoreactivity when stained with MAB2166 [10]. Therefore, we find MAB2166 antibody to be highly specific to endogenous $\mathrm{Htt}$ in rodent neurons. We next detected BDNF mRNA in cortical neurons by fluorescent in situ hybridization (FISH) using the BDNF coding sequence as probe (Fig. 1b). The BDNF mRNA was visualized in the form of RNA granules, which may contain multiple (up to 30 ) RNA molecules $[14,15]$. We found BDNF mRNA to co-localize with $\mathrm{Htt}$ in granules, consistent with our previous finding that $\mathrm{Htt}$ is present in neuronal RNA granules and co-localizes with mRNAs [10].

\section{Co-localization of Htt with BDNF-3'UTR mRNA in cortical neurons}

To examine further the association of Htt with BDNF mRNA in neurons, we used the MS2-fluorescent reporter RNA localization system to test if endogenous $\mathrm{Htt}$ can be detected in RNA granules that contain BDNF-
3'UTR mRNA (Fig. 1c). This system has been used previously to investigate the role of an RNA-binding protein in dendritic transport of target mRNA [16]. Cortical neurons in culture were transfected with NLS-MS2Venus, and an RNA localization reporter plasmid expressing BDNF-3'UTR fused to the binding sequence (MS2bs) of the bacteriophage MS2 protein. The BDNF 3'UTR region generates alternative polyadenylated mRNAs, one ending at $0.35 \mathrm{~kb}$ and another at $2.85 \mathrm{~kb}$ downstream of the stop codon [17]. A previous study reported differential localization of the two BDNF mRNA populations in neurons; however, the basis for this phenomenon remains unclear [18]. We examined three RNA reporter constructs containing full-length $(2.85 \mathrm{~kb})$, short $(0.35 \mathrm{~kb})$ and long $(2.5 \mathrm{~kb})$ BDNF 3'UTR sequence. Staining for endogenous Htt showed significant co-localization with all three BDNF-3'UTR reporters (detected by NLS-MS2-Venus) in cortical dendrites (Fig. 1d-f). Quantitative analysis of one projection from the image stack shows $35.7 \%$ of short 3'UTR, $38.8 \%$ of long 3'UTR and $31.5 \%$ of full-length 3'UTR to co-localize with endogenous $\mathrm{Htt}$. This result suggests that Htt co-localizes with BDNF-3'UTR mRNA in dendrites. We did not detect significant differences among the reporters containing different lengths of the BDNF 3'UTR sequence. Using live-cell imaging, we also examined the localization of transfected RFP-Htt480-17Q and BDNF-3'UTR short mRNA (detected by NLS-MS2Venus) in cortical neurons (Fig. 2). Htt was found to co-traffic with BDNF 3'UTR short mRNA in granules moving from the periphery towards the cell soma, indicating that $\mathrm{Htt}$ may be involved in retrograde dendritic trafficking of BDNF mRNA through its 3'UTR (Fig. 2 and additional file 1).

\section{Improved method to co-localize endogenous proteins with RNA in brain tissue}

To study the co-localization of $\mathrm{Htt}$ and associated proteins with specific mRNAs in the brain, we used immunofluorescence staining (IFS) and FISH. Because of the problems in applying both FISH and IFS to thick vibratome-generated sections of rat brain tissue, and the limited sensitivity and high background of most methods, we employed a new approach using three-dimensional (3D) reconstruction on serial confocal images to visualize mRNA and proteins at high resolution. This 3D reconstruction avoids time-consuming and tedious tissue section processing and provides an accurate distribution of mRNA and proteins while retaining their status in situ.

A series of optimization and troubleshooting steps, described in Table 1, was carried out to maximize the signal detection in tissue sections. For combined FISH and IFS of thick vibratome sections, one challenge is to 

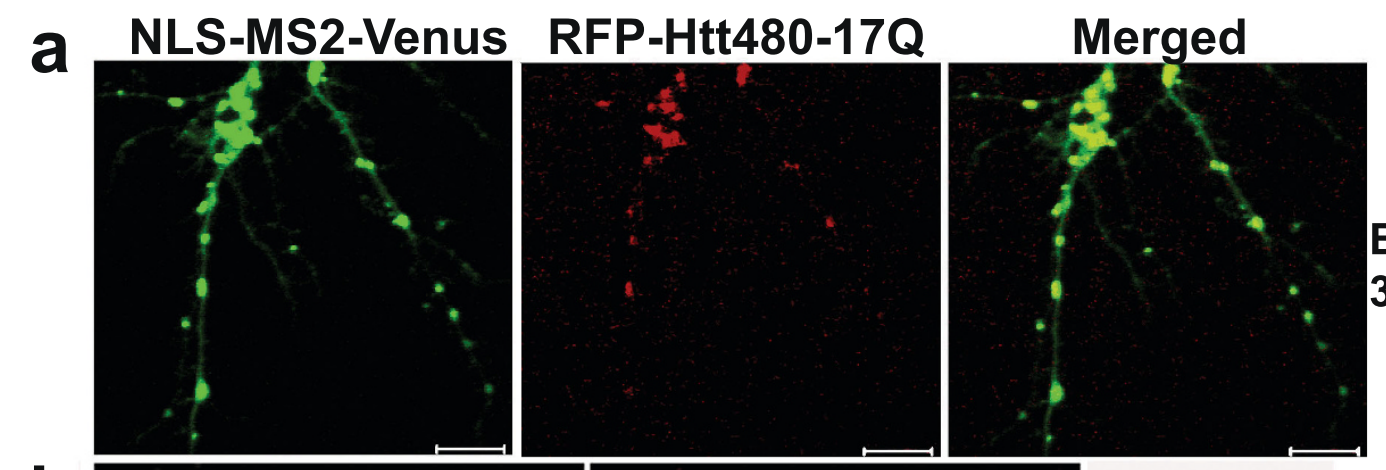

BDNF short

b

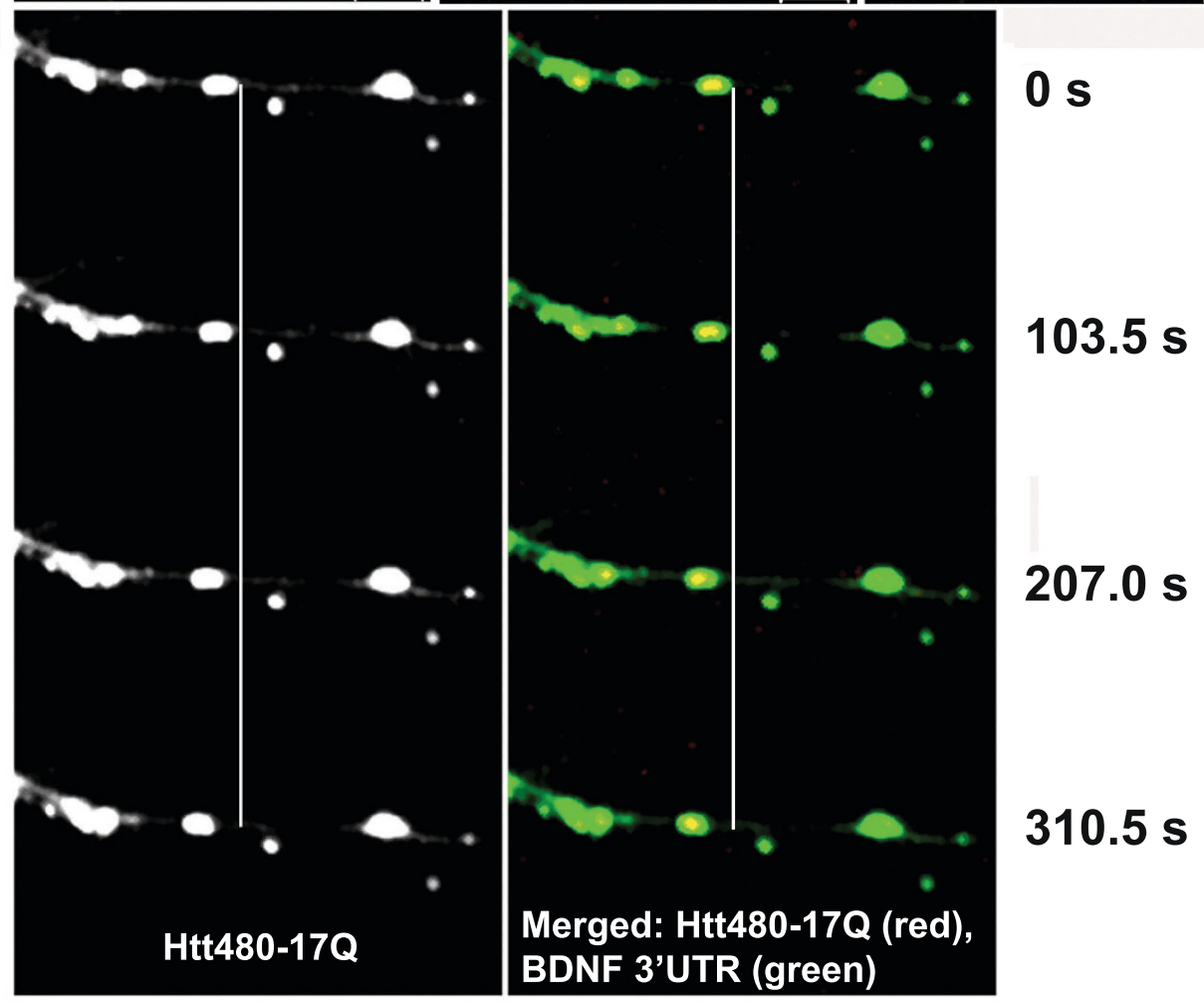

Figure 2 Co-trafficking of Htt with BDNF 3'UTR mRNA in rat cortical neurons. (a) The BDNF mRNA reporter plasmid with short 3'UTR was co-transfected with plasmids expressing NLS-MS2-Venus and RFP-Htt480-17Q and examined by live-cell imaging. BDNF mRNA is shown in green (detected by NLS-MS2-Venus) and Htt in red. Htt co-localizing with BDNF mRNA is in yellow in merged images. (b) Four cropped images from a time-lapse series in (a) captured over 310.5 seconds. Htt is shown in grayscale and the merged image in yellow. Vertical white line is drawn through the four panels to highlight the movement of one mRNA granule (left of the white line) over time. The distance that the granule traveled was $1.76 \mu \mathrm{m}$. Scale bar: $10 \mu \mathrm{m}$.

improve tissue permeabilization conditions to allow effective diffusion of probes for greater access to target mRNA and antigen. We found treatment with $0.25 \%$ Triton X-100 overnight at $4^{\circ} \mathrm{C}$, or 2 hours at room temperature was effective in enhancing permeability of the sections (up to $30 \mu \mathrm{m}$ ) resulting in the immunodetection of intracellular proteins such as Ago2 and dynein. To detect low copy mRNAs (minimal 10-20 copies) in neurons, we developed a detection system utilizing polyclonal chicken $\alpha$-digoxigenin (DIG) and goat $\alpha$-chicken antibodies. We found that the use of tyramide signal amplification to enhance signal detection $[18,19]$ required multiple blocking and incubation steps and displayed low resolution. In our method, FISH detection of BDNF mRNA could be performed with protein detection simultaneously without additional steps. We have utilized our improved approach to study the co-localization of the proteins $\mathrm{Htt}$, Ago2, cytoplasmic polyadenylation element-binding protein 1 (CPEB1) and dynein, with BDNF mRNA as described below. 
Table 1 Troubleshooting Guidelines

\begin{tabular}{|c|c|c|}
\hline Problem & Possible reason & Solution \\
\hline \multirow[t]{4}{*}{ No or weak hybridization signal } & Probe degradation & $\begin{array}{l}\text { Check probe on DNA gel. } \\
\text { If necessary, synthesize new probe. }\end{array}$ \\
\hline & Probe concentration too low & $\begin{array}{l}\text { Use more probe. } \\
\text { Use longer hybridization time. }\end{array}$ \\
\hline & mRNA degradation & $\begin{array}{l}\text { Optimize perfusion and post-fixation conditions. } \\
\text { Ensure that solutions, containers and instruments are RNase-free. }\end{array}$ \\
\hline & $\begin{array}{l}\text { Inadequate immunofluorescent detection of } \\
\text { DIG-labeled probes }\end{array}$ & $\begin{array}{l}\text { Titrate anti-hapten antibody. } \\
\text { Replace with new antibody. } \\
\text { Replace with more sensitive detection system (e.g. polyclonal } \\
\text { anti-hapten). } \\
\text { Use brighter fluorescent dye conjugated antibodies (e.g. Dylight). }\end{array}$ \\
\hline $\begin{array}{l}\text { FISH signal detected on section } \\
\text { surface only }\end{array}$ & Poor permeabilization & $\begin{array}{l}\text { Use longer incubation time or optimize detergent concentration. } \\
\text { Use thinner sections. } \\
\text { Use shorter probe or oligonucleotide probe. }\end{array}$ \\
\hline \multirow{4}{*}{$\begin{array}{l}\text { Non-specific and/or high } \\
\text { background staining }\end{array}$} & Probe not well purified & Optimize purification steps. \\
\hline & Hybridization conditions not optimal & $\begin{array}{l}\text { Reduce time of hybridization. } \\
\text { Reduce probe amount. } \\
\text { Increase time and volume of post-hybridization washes. } \\
\text { Increase concentration of serum in blocking steps. } \\
\text { Use } 4^{\circ} \mathrm{C} \text { for incubation with secondary antibodies. } \\
\text { Use gentle shaking for hybridization, washing steps. } \\
\text { Avoid sections drying out. }\end{array}$ \\
\hline & Hybridization of probes to unwanted mRNAs & $\begin{array}{l}\text { Use coding sequence only instead of entire plasmid or shorter } \\
\text { sequence for probe generation. } \\
\text { Use sequence-specific probes. } \\
\text { Use oligonucleotide probes. }\end{array}$ \\
\hline & $\begin{array}{l}\text { Immunofluorescent detection of DIG-labeled } \\
\text { probes not optimal }\end{array}$ & $\begin{array}{l}\text { Adjust concentration of anti-DIG and/or anti-chicken antibodies. } \\
\text { Spin antibody before use. } \\
\text { Use another detection system. }\end{array}$ \\
\hline
\end{tabular}

\section{Visualization of $\mathrm{Htt}$, Ago2 with BDNF mRNA}

Due to the localization of BDNF mRNA in somato-dendritic compartments in the hippocampus and cortex $[20,21]$ and its prominent relationship with $\mathrm{Htt}$, we utilized new enhancements to carry out both FISH and IFS together. To detect BDNF mRNA, DIG-labeled DNA probes were generated from a plasmid containing BDNF 3'UTR (see Methods). After hybridization, vibratome sections were probed with $\alpha$-Htt and $\alpha$-Ago 2 antibodies. A representative 3D projection image is shown in Fig. 3a. No FISH signal was observed with probes generated from the control vector only plasmid (Fig. 3b). Using the co-localization analysis function of the Zeiss LSM software, we quantified percent co-localization of BDNF mRNA, Htt and Ago2 proteins in the P11 rat brain cortex (Fig. 3c). We found co-localization percentage for each pair of proteins and protein-mRNA ranging between 12 and $25 \%$.

\section{Seven-color segmentation}

Combined multicolor FISH and IFS represent a powerful way of visualizing the spatial and temporal relationship between mRNA and proteins in histological sections. However, for better visualization and interpretation of the image data, an automatic color segmentation method is needed. Because showing seven colors in one composite image is difficult for further analysis, color segmentation should be ideally made to generate six or seven pseudo channels, each of which representing a specific or a co-localizing target. In this study, a vector-based sevencolor segmentation approach was applied on one composite image (Fig. 4a-b) from a 3D projection and the seven pseudo-channels were generated (Fig. 4c-d). The yellow channel represents co-localizing puncta of BDNF mRNA and $\mathrm{Htt}$, the magenta channel co-localizing puncta of BDNF mRNA and Ago2, and the cyan channel co-localizing Htt and Ago2. The seventh pseudo channel is shown in panel d: white signal is the color addition product of three primary colors green, red and blue, representing the co-localization of Htt, BDNF mRNA and Ago2. Thus, this method offers visualization of the in situ location of protein pairs or protein and RNA from a single image.

\section{Visualization of $\mathrm{Htt}$, CPEB1, dynein with BDNF mRNA}

To extend these findings, the expression of BDNF mRNA was analyzed with Htt and CPEB1, a protein responsible for recognition of cytoplasmic polyadenylation elements 

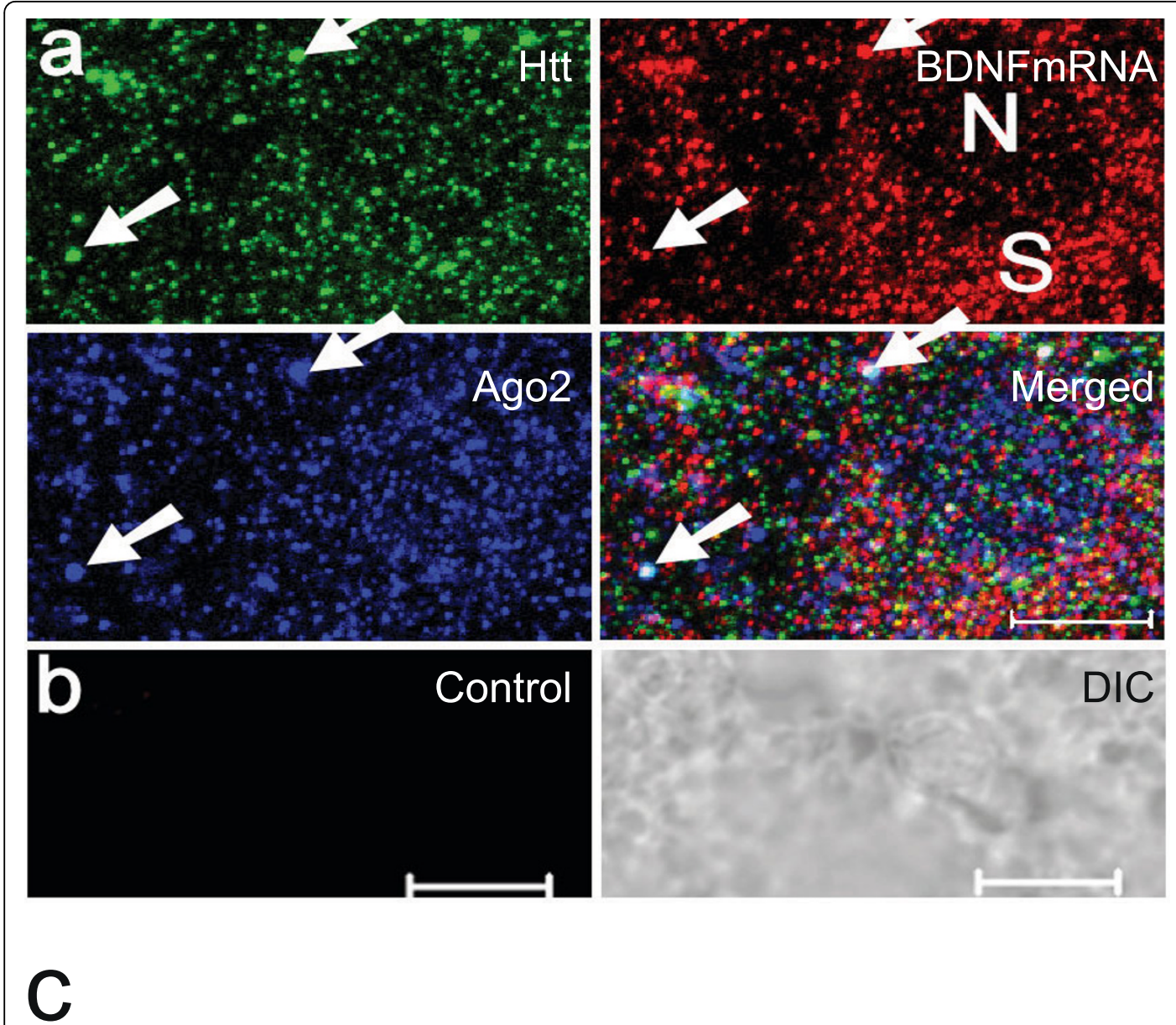

\begin{tabular}{|l|c|c|c|}
\hline & Htt & BDNF 3'UTR mRNA & Ago2 \\
\hline Htt & ---- & $16.6 \%$ & $18.1 \%$ \\
\hline BDNF 3'UTR mRNA & $14.8 \%$ & ---- & $12.2 \%$ \\
\hline Ago2 & $25.3 \%$ & $18.9 \%$ & ---- \\
\hline
\end{tabular}

Figure 3 Visualization of BDNF mRNA with $\mathrm{Htt}$ and Ago2 proteins in vibratome sections of a P11 rat brain cortex. (a) A 3D projection of serial optical sections obtained by confocal microscopy. BDNF mRNA, Htt and Ago2 are shown in red, green and blue, respectively. Reconstruction method: LSM software, optical slice interval: $0.5 \mu \mathrm{m}$, stack size: $6.0 \mu \mathrm{m}$, N: nucleus, S: soma. White arrow indicates one co-localizing puncta of BDNF mRNA with Htt and Ago2. Scale bar: $5 \mu \mathrm{m}$. (b) Control FISH with a nick-translated probe generated from a control plasmid. DIC: differential interference contrast. Scale bar: $5 \mu \mathrm{m}$. (c) Percent co-localization of BDNF 3'UTR mRNA with Htt and Ago2. 16.6\% and $18.1 \%$ of $\mathrm{Htt}$ was found to co-localize with BDNF mRNA and Ago2, respectively. $14.8 \%$ and $12.2 \%$ of BDNF mRNA was found to co-localize with $\mathrm{Htt}$ and Ago2, respectively.

(CPEs) and regulating poly (A) length. Representative reconstruction results are shown in Fig. 5a-b and additional file 2 . The $3 \mathrm{D}$ temporal and spatial relationship and the co-localization of individual BDNF mRNAcontaining granules with Htt and CPEB1 in vibratome sections were demonstrated by high-resolution reconstruction (Fig. 5c and additional file 3). Quantitative analysis of one projection from the CPEB1 image stack was as follows: $37.6 \%$ of BDNF mRNA co-localized with CPEB1, 17.1\% of CPEB1 co-localized with BDNF mRNA, $20.0 \%$ of Htt co-localized with CPEB1, and 22.0\% CPEB1 co-localized with Htt. These results confirm that Htt and BDNF mRNA are in close proximity to the machinery involved in RNA processing.

Previous investigations indicated that $\mathrm{Htt}$ and dynein subunits directly interact [22,23], and that Htt plays a 

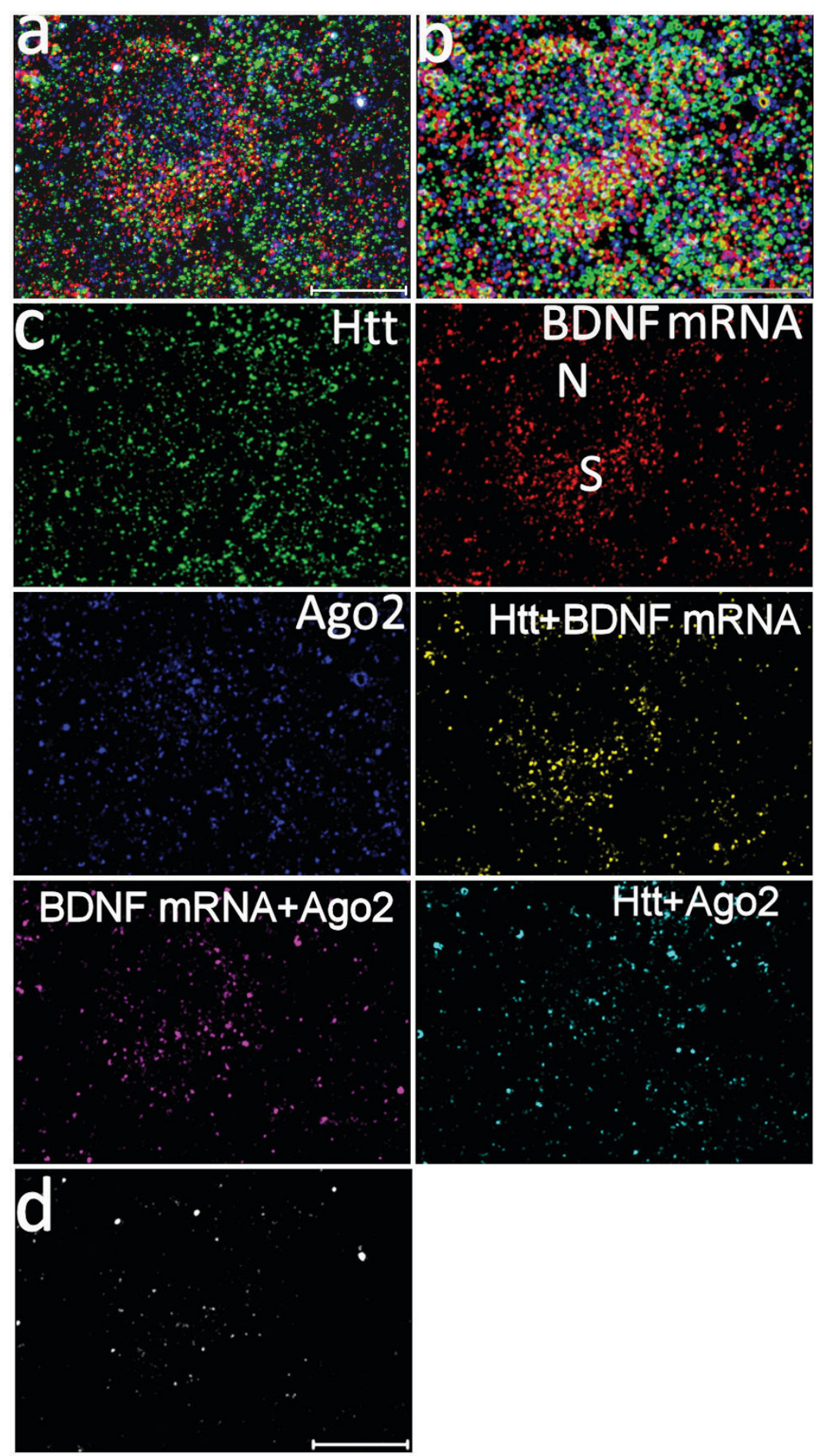

Figure 4 Seven-color segmentation of a composite confocal image (3D projection) to analyze mRNA/protein and protein/protein co-localization in a rat brain slice. Scale bar: $10 \mu \mathrm{m}$. (a) Composite image (merged from three channels) taken from Fig. 3a. BDNF mRNA, Htt and Ago2 are shown in red, green and blue, respectively. (b) An artificial presentation of (a) to demonstrate distribution of different color pixels in (a). (c) Image in (a) was segmented using self-programmed software integrated in ImageJ to generate seven pseudo channels, each of which represents single or co-localized target(s). The secondary colors yellow, cyan and magenta indicate overlap of green (Htt) and red (mRNA), green ( $\mathrm{Htt}$ ) and blue (Ago2), red (mRNA) and blue (Ago2), respectively. The seventh pseudo channel is shown in (d). N: nucleus, S: soma. (d) White signal is the color addition product of three primary colors green, red and blue, representing co-localization of Htt, BDNF mRNA and Ago2. Due to the limitations in the co-localization analysis function of the LSM software for confocal microscope, we can calculate percent localization for double but not triple co-localization. 


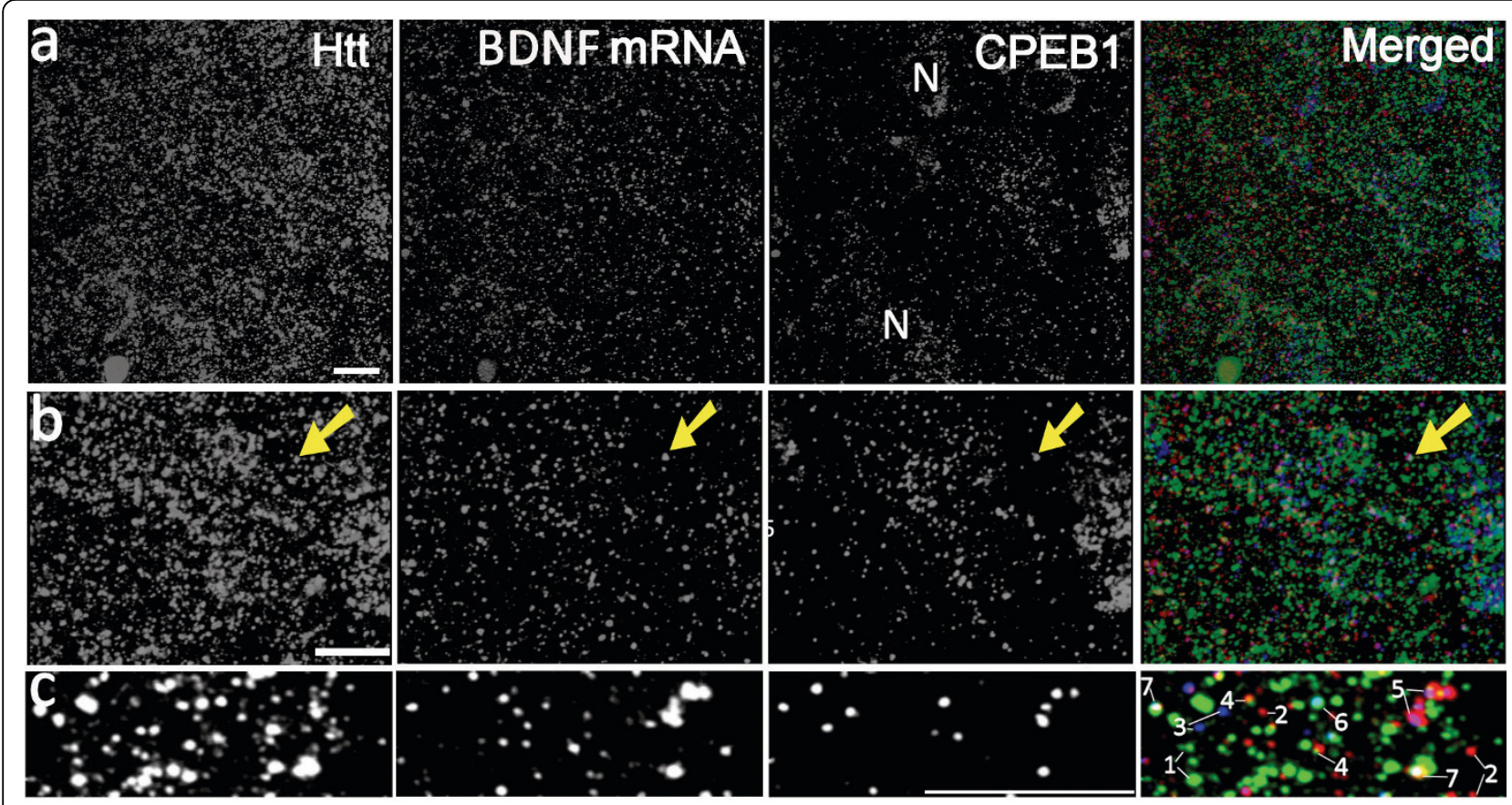

Figure 5 Visualization of BDNF mRNA with $\mathrm{Htt}$ and mRNA-binding protein CPEB1 in vibratome sections of a rat brain cortex. (a) In merged panels, BDNF mRNA, Htt and CPEB1 were imaged in red, green and blue, respectively. The three left hand columns are presented in black and white. Reconstruction method: ImageJ, optical slice interval: $0.5 \mu \mathrm{m}$, stack size: $16.0 \mu \mathrm{m}$, rotation angle: $0^{\circ}$. N: Nucleus (b) Image stack in (a) was cropped for high-resolution 3D reconstruction. Yellow arrow indicates one co-localizing puncta of BDNF mRNA with Htt and CPEB1. Co-localized spots appear white in the merged panel. N: Nucleus. (c) High-resolution 3D presentation of (a) to demonstrate spatial relationship of Htt/BDNF mRNA/CPEB1. Rotation angle: $170^{\circ}$. Htt, BDNF mRNA and CPEB1 correspond to 1, 2, 3, respectively. Co-localization of Htt/mRNA (yellow), mRNA/CPEB1 (magenta), Htt/CPEB1 (cyan) and Htt/mRNA/CPEB1 (white) correspond to 4, 5, 6, 7, respectively.

critical role in the transport of intracellular vesicles and proteins [24]. Although transport of BDNF protein occurs in an anterograde and retrograde manner [25], there is little information with regard to the localization of BDNF mRNA in structures associated with microtubule-based molecular motors. To confirm the interaction of $\mathrm{Htt}$ and dynein and extend the analysis to BDNF mRNA, we carried out nick-translation of the BDNF coding sequence DNA in order to detect BDNF mRNA in rat brain sections. The sections were subsequently probed with $\alpha$-Htt and $\alpha$-dynein (HC) antibodies.

One representative image of a two-dimensional (2D) optic slice is shown in Fig. 6a-b. The results of colocalization analysis of BDNF mRNA and dynein are shown in Fig. 6c. Using the same method described for Ago2 (Fig. 3), the co-localizing puncta of Htt/mRNA/ dynein were quantified (Fig. $6 \mathrm{~g}$ ). We found $9.3 \%$ of BDNF mRNA to co-localize with $\mathrm{Htt}$ and $4.6 \%$ of dynein to co-localize with Htt. Using the LSM software, the image stack was reconstructed; one $3 \mathrm{D}$ projection is shown in Fig. 6d-e. For visualizing the co-localization events in 3D, the whole image stack was segmented and then reconstructed with the LSM software (Fig. 6f). The combinatorial approach including multicolor FISH/IFS and associated co-localization analysis indicates that Htt and dynein can be found in close proximity to BDNF mRNA.

\section{Discussion}

Previous studies have indicated that Htt serves as a scaffold protein during the process of axonal transport of BDNF [7]. Anterograde transport of BDNF from the cortex provides trophic support to striatal neurons. Lack of cortical BDNF gives rise to atrophy and death of striatal cells [26]. In addition to axonal transport of BDNF, transcription of the BDNF gene was also reported deregulated in Huntington's disease $[7,8]$. Reduced BDNF levels lead to a higher susceptibility of neurons to cell death in several neurodegenerative diseases including HD [27] and Alzheimer's disease [28]. An emerging regulatory mechanism suggests that targeting of BDNF mRNA occurs in specific dendritic sites after changes in neuronal activity or high frequency stimulation [29]. Although BDNF mRNA in cortical dendrites will not reach the striatum, changes in cortical BDNF levels could affect survival of striatal cells. Dendritic translation of BDNF mRNA can regulate morphological changes in spines [12]. The rodent BDNF gene is 


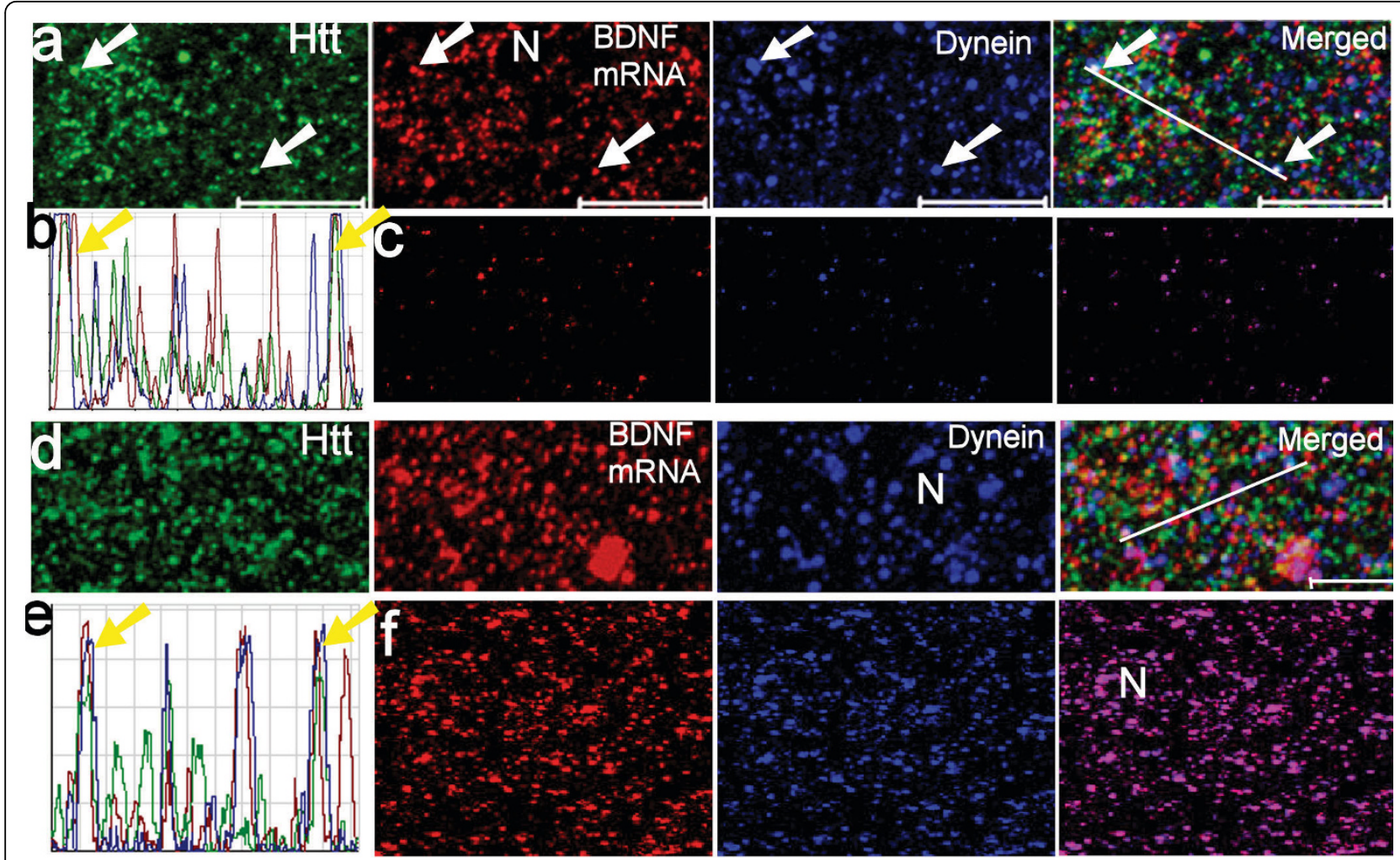

g

\begin{tabular}{|l|c|c|c|}
\hline & $\mathrm{Htt}$ & BDNF mRNA & Dynein \\
\hline $\mathrm{Htt}$ & ---- & $13.0 \%$ & $15.8 \%$ \\
\hline BDNF mRNA & $9.3 \%$ & ---- & $4.9 \%$ \\
\hline Dynein & $4.6 \%$ & $3.8 \%$ & ---- \\
\hline
\end{tabular}

Figure 6 Visualization of BDNF mRNA with Htt and dynein in vibratome sections of a rat brain cortex. White arrow indicates co-localization of BDNF mRNA with Htt and dynein in the images, while yellow arrow indicates co-localization of BDNF mRNA with Htt and dynein in the diagram. Co-localized spots appear white in the merged panel. N: Nucleus. (a) An optic slice from confocal microscopy. BDNF mRNA, Htt and dynein are shown in red, green and blue, respectively. Scale bar: $10 \mu \mathrm{m}$. (b) A diagram showing intensity profile of pixels underlying the white line drawn in the merged panel in (a). (c) Co-localization analysis of BDNF mRNA and dynein using the LSM software. (d) 3D projection of image stack of 37 optical slices. Reconstruction method: LSM software, optical slice interval: $0.5 \mu \mathrm{m}$, stack size: $18.0 \mu \mathrm{m}$, rotation angle: $0^{\circ}$. (e) Intensity profile of pixels underlying the white line drawn in the merged panel in (d). (f) 3D co-localization analysis of mRNA and dynein in image stack. The pixels in red channel (mRNA) and blue channel (dynein) were segmented using a 2D thresholding approach of the whole stack and segmented stacks were reconstructed using the LSM software. One projection at rotation angle $0^{\circ}$ is shown. (g) Percent co-localization of BDNF mRNA (exon 2c, 4, 6, 8, 9) with Htt and dynein.

transcribed by multiple promoters and generates at least 22 different transcripts [30,31]. The function of each mRNA isoform has yet to be characterized. One hypothesis is that different BDNF mRNAs are directed to different subcellular locations and may be locally translated and released, providing a means to selectively regulate dendritic architecture in restricted domains [21].

We previously reported that $\mathrm{Htt}$ co-localizes with Ago2 in processing (P)-bodies of somatic cells and neuronal granules $[9,10]$ suggesting that $\mathrm{Htt}$ may play a role in RNA processing and/or gene silencing. To determine if $\mathrm{Htt}$ co-localizes with specific mRNAs in neuronal granules, which are structurally and functionally related to P-bodies [32], we utilized multicolor IFS and FISH techniques in concert with 3D co-localization to follow the expression of individual molecules in rat brain. We performed co-localization analysis on neurons and vibratome sections to study the interaction of proteins with BDNF mRNA. This is a number-based analysis; i.e., we analyze co-localization of BDNF mRNA granules and 
puncta staining of proteins. It differs from intensitybased analysis, which represents the total amount of mRNA molecules present in the granules. The discovery that BDNF mRNA is associated with Ago2 and Htt suggests a new mechanism for BDNF gene expression mediated through mRNA processing in neuronal granules.

Post-transcriptional control of BDNF mRNA in the brain likely plays a role in the production of BDNF protein [29]. While little is known about BDNF mRNA processing in neuronal granules, mechanisms of dendritic trafficking of BDNF mRNA are starting to emerge. A recent study showed that the mutation G196A (Val66Met) in the BDNF coding sequence, which is linked to impaired episodic memory and depression in humans, disrupts a recognition site in BDNF mRNA for the RNA-binding protein translin [13]. Reduced binding by translin at the 196A site was found to block trafficking of (Met)-BDNF mRNA in dendrites. Remarkably, it was previously reported that Met-carrier mice have reduced dendritic arborization and display more anxiety-like behavior similar to that of humans [33,34]. Thus, impairment of BDNF mRNA sorting and processing is likely involved in the pathogenesis of specific neuronal diseases such as HD and other psychiatric disorders. Indeed, the results shown in the present study represent a first clue that normal Htt may function in post-transcriptional repression pathways of BDNF mRNAs through P-bodies/neuronal granules and its retrograde dynein-mediated transport in dendrites. Further studies are warranted to determine how mutant $\mathrm{Htt}$ affects BDNF mRNA trafficking and RNA processing.

Combined multicolor FISH and IFS represent a powerful way of visualizing the spatial relationship between mRNA and proteins in histological sections. In this study, several experimental conditions have been optimized in order to perform mRNA FISH on brain tissue sections. First, brain sections need to be well fixed so that the low copy target mRNAs are protected and retained in their native location. Second, the sections need be properly processed to improve permeability, enabling probes and antibodies to reach their target. Treatments with proteinase $\mathrm{K}$, sodium borohydride, ethanol gradient, or methanol have been previously applied for preprocessing tissue sections for FISH [18,35-37]; however, these steps are time-consuming and may have negative effects on signal detection. Third, to enhance the signal detection in tissue sections, methods such as tyramide signal amplification may be necessary $[18,19]$. Indeed, a combination of FISH and IFS may be difficult because immunodetection signal is likely weaker following FISH.

Using a number of improvements that address these shortcomings, we were able to visualize at high resolution the co-localization of BDNF mRNA with $\mathrm{Htt}$ and Ago2 at a single neuron level. These results suggest that Htt may play a role in post-transcriptional transport/targeting of mRNA through association with neuronal RNA granules. The targeting/trafficking of mRNA is a complex and dynamic process. The RNA-containing granules contain multiple proteins including Htt, RNAbinding proteins, motor proteins, and microtubules. Assembly/disassembly of protein/protein and protein/ RNA complexes likely occur through multiple signaling pathways. Therefore, it is difficult to know whether the observed small percentage of BDNF mRNA co-localizing with Ago2 and Htt suggests involvement of a labile component. We also demonstrated the co-localization of $\mathrm{Htt}$ and BDNF mRNA with dynein, a motor protein involved in retrograde transport of cargos including mRNA [38]. We have also demonstrated that the 3'UTR of BDNF mRNA and Htt co-localize and co-traffic in cortical neurons. Together these findings implicate a role for $\mathrm{Htt}$ in maintaining neurotrophic support and neuron survival via delivery and processing of BDNF mRNA.

\section{Conclusions}

We report the co-localization of BDNF mRNA with Htt, Ago2, CPEB and dynein in cultured cortical neurons and the rat cortex. Our combined approach of IFS/FISH and co-localization analysis provides a powerful means to study protein-mRNA interaction in neuronal cells or tissues. We show that the 3'UTR of BDNF mRNA and $\mathrm{Htt}$ co-localize and co-traffic in cortical neurons. These results suggest that Htt may play a role in post-transcriptional transport/targeting of mRNA through association with neuronal RNA granules. The findings implicate a role for $\mathrm{Htt}$ in maintaining neurotrophic support and neuron survival via delivery and processing of BDNF mRNA.

\section{Methods}

\section{Brain fractionation}

Brain fractions were generated as described [39]. Briefly, one flash frozen P15 Swiss Webster mouse brain was minced into a paste and homogenized on ice in a glass Dounce homogenizer in $2 \mathrm{ml}$ of Buffer A $(10 \mathrm{mM}$ HEPES, $\mathrm{pH} 7.6$; $1.5 \mathrm{mM} \mathrm{MgCl}_{2}$ ) containing protease inhibitors (leupeptin, pepstatin, aprotinin, PMSF, and sodium metabisulfite) and RNAse inhibitor (40 units RNAsin, Promega). The homogenate was incubated on ice for 10 minutes after which $1 / 10$ volume of $10 \times$ Buffer B (300 mM HEPES, pH 7.6; $1.4 \mathrm{M} \mathrm{KCl}, 30 \mathrm{mM} \mathrm{MgCl}_{2}$ ) was added. Homogenate was spun at $1,400 \times g$ for 10 minutes at $4^{\circ} \mathrm{C}$ to pellet the P1 fraction. The P1 fractions were washed in $1 \mathrm{ml}$ of $1 \times$ Buffer $B$ and spun as before. The combined supernatants from the $1,400 \times g$ spin were 
spun for 20 minutes at $14,000 \times g$ at $4^{\circ} \mathrm{C}$ to pellet the P2 fraction. The supernatant $(\mathrm{S} 2)$ was spun for an additional 2 hours at $100,000 \times g$ at $4^{\circ} \mathrm{C}$ to pellet the P3 fraction. Fraction P1 was resuspended in one-half the volume of total S3, fraction P2 was resuspended in same volume as total S3, and fraction P3 was resuspended in 1/10 volume of total S3. $50 \mathrm{mg}$ of S3 and equivalent volumes of P1, P2, and P3 fractions were loaded onto a 7.5\% SDS polyacrylamide gel for electrophoresis.

\section{Western blotting}

$50 \mu \mathrm{g}$ of S3 and equivalent volumes of P1, P2, and P3 fractions were loaded onto a $7.5 \%$ SDS polyacrylamide gel for electrophoresis and transferred to nitrocellulose membrane, blocked for 1 hour in 5\% nonfat dry milk in TBST at room temperature, and incubated in a 1:1000 dilution of MAB2166 (Millipore) in TBST overnight at $4^{\circ} \mathrm{C}$. IR Dye 800 conjugated goat anti-mouse secondary antibody was used at 1:10000. Blot was scanned on a LI-COR Odyssey infrared scanner (LI-COR, Lincoln, $\mathrm{NE})$.

\section{Preparation of nick-translated probes}

DIG-labeled DNA probes were generated using DIGNick Translation Mix (Roche Applied Science) according to manufacturer's protocol. $1.0 \mu \mathrm{g}$ RLTK plasmid DNA (Promega) containing BDNF 3'UTR only, or $1.0 \mu \mathrm{g}$ of a mixture of plasmid DNA each $(0.25 \mu \mathrm{g})$ containing exon2c, exon4, exon6, or exon 8 of the BDNF gene linked to the protein coding sequence (exon9) of BDNF and fused with GFP at the 3' end [13]. The latter probe mix was used to detect "BDNF mRNA" in the current study. RLTK plasmid without any insert was used as a control. After nick-translation, Illustra ProbeQuant $^{\text {TM }}$ G-50 Micro Columns (GE Healthcare) were used for probe purification. $1.0 \mu \mathrm{g}$ template DNA yielded $50 \mu \mathrm{l}$ of probe. Probes of 200-400 bp in length were used for hybridization.

\section{Preparation of vibratome sections}

Female wild-type Wistar rats (2 or 3 weeks old, Harlan Laboratories, Indianapolis, IN) were perfused transcardially with PBS ( $\mathrm{pH} 7.4$ ), followed by $4 \%$ paraformaldehyde (PFA, Electron Microscopy Sciences, Hatfield, PA) under deep anesthesia induced by i.p. injection of a mixture of ketamine $(100 \mathrm{mg} / \mathrm{kg})$ and xylazine $(25 \mathrm{mg} / \mathrm{kg})$. Brain tissues were extracted from the skull, post-fixed with $4 \% \mathrm{PFA} / 20 \%$ sucrose for at least two days at $4{ }^{\circ} \mathrm{C}$. All rats were maintained under veterinary supervision at New York University School of Medicine Animal Care Facility in accordance with the guidelines established by the NIH for the care of laboratory animals and all procedures approved by the Institutional Animal Care and Use Committee. $100 \mu \mathrm{m}$ vibratome sections were prepared with a Vibratome Series 1000 Classic (Vibratome Company, St. Louis, MO) and transferred to 24-well plates filled with DEPC-PBS.

\section{Fluorescence in situ hybridization of mRNA}

DEPC-treated water was used for preparation of PBS and other reagents. The sections were treated with $0.25 \%$ Triton X-100 in PBS overnight at $4{ }^{\circ} \mathrm{C}$ and washed 3 times with PBS. After 20 minute rinsing in $1 \times \mathrm{SSC}$, the sections were incubated for 2 hours at $37^{\circ} \mathrm{C}$ with $100 \mu \mathrm{l}$ hybridization buffer [25\% dextran sulfate, $30 \mu \mathrm{g} / \mathrm{ml}$ single stranded salmon sperm DNA (Sigma), $30 \mu \mathrm{g} / \mathrm{ml}$ yeast tRNA (Sigma), 0.4\% bovine serum albumin (Jackson ImmunoResearch Laboratories), $20 \mathrm{mM}$ ribonucleoside vanadyl complex (Sigma), 0.01 M sodium phosphate buffer ( $\mathrm{pH} 7.0$ ), $2 \times \mathrm{SSC}$ ]. The sections were then hybridized for 12 hours at $37^{\circ} \mathrm{C}$ with $5 \mu \mathrm{l}$ of nick-translated probe diluted in $100 \mu$ l hybridization buffer. After hybridization, sections were washed with $40 \%$ formamide $11 \times$ SSC for 1 hour at $37^{\circ} \mathrm{C}$ with gentle shaking, followed by $3 \times 30$ minute washing with $1 \times$ SSC with gentle shaking on an orbital shaker.

\section{Detection of DIG-labeled probes and immunofluorescence staining}

Primary antibodies used in the study are listed in Table 2 . All dilutions and washes $(3 \times 30$ minutes $)$ between stages were performed in PBS unless otherwise stated. Vibratome sections were washed for 20 minutes in PBS, blocked with $5 \%$ goat serum (Sigma) for 2 hours, and incubated overnight at $4{ }^{\circ} \mathrm{C}$ with primary antibodies (in solution containing $5 \%$ goat serum). They were then incubated overnight at $4^{\circ} \mathrm{C}$ with secondary antibodies. After immunolabeling, they were transferred to Lab-Tek 2-well chamber cover glass (Nalge Nunc International) for analysis. For improved observation, a piece of cover slip $(12 \mathrm{~mm})$ was placed over the section to anchor it to the bottom of the chamber cover glass. Detection of DIG-labeled probes was carried out by incubating sections with chicken $\alpha$-DIG antibody (Immunology Consultants Laboratory, Newberg, OR), followed by incubation with Dylight 549-conjugated goat $\alpha$-chicken IgY (IgG) (Jackson ImmunoResearch Laboratories). Htt was detected by incubating sections with mouse $\alpha-\mathrm{Htt}$ (Millipore), followed by Alexa 488-conjugated goat $\alpha$ mouse IgG (Invitrogen). Ago2, dynein and CPEB1 were detected by incubating sections with rabbit $\alpha$-Ago2 (gift of Ramin Shiekhattar, The Wistar Institute, PA), rabbit $\alpha$-dynein HC (Santa Cruz Biotechnology) and rabbit $\alpha$-CPEB1 (gift of David Wells, Yale University) antibodies, followed by Dylight 649-conjugated goat $\alpha$-rabbit IgG (Jackson ImmunoResearch Laboratories). FISH of primary neurons was performed with a similar procedure with less processing time for incubation and washing. 
Table 2 Antibodies used in the study

\begin{tabular}{|c|c|c|c|c|}
\hline Antibody & Immunogen & Source & $\begin{array}{l}\text { Host } \\
\text { species }\end{array}$ & Isotype, Dilution used \\
\hline anti-DIG & digoxigenin conjugated with KLH & $\begin{array}{l}\text { Immunology Consultants } \\
\text { Laboratory, CDIG-65A }\end{array}$ & chicken & polyclonal $\lg Y, 1: 500$ \\
\hline anti-Htt & $\begin{array}{l}\text { human huntingtin protein a.a. } \\
\text { 181-810 }\end{array}$ & Millipore, MAB2166 & mouse & $\begin{array}{l}\text { monoclonal, lgG1 } \kappa \\
\text { clone } 1 \mathrm{HU}-4 \mathrm{C} 8,1: 500\end{array}$ \\
\hline anti-Ago2 & $\begin{array}{l}\text { human Ago2 peptide } \\
\text { KLMRSASFNTDPYVRE }\end{array}$ & $\begin{array}{l}\text { Gift of Ramin Shiekhattar, The } \\
\text { Wistar Institute }\end{array}$ & rabbit & polyclonal, 1:1000 \\
\hline anti-dynein $\mathrm{HC}$ & $\begin{array}{l}\text { rat dynein heavy chain a.a. } \\
4320-4644\end{array}$ & Santa Cruz Biotechnology, sc-9115 & rabbit & polyclonal, lgG, 1:300 \\
\hline anti-CPEB1 & $\begin{array}{l}\text { mouse CPEB1 peptide } \\
\text { SMEGLRHHSPLMRNQKN }\end{array}$ & Gift of David Wells, Yale University & rabbit & polyclonal, lgG, 1:1000 \\
\hline $\begin{array}{l}\text { Alexa Fluor } 488 \text { goat anti- } \\
\text { mouse lgG }\end{array}$ & mouse $\lg G(H+L)$ & Invitrogen, A-11001 & goat & polyclonal, 1:500 \\
\hline$\overline{C y 3}$ goat anti-mouse IgG & mouse $\lg G(H+L)$ & $\begin{array}{l}\text { Jackson ImmunoResearch, } \\
\text { 115-166-003 }\end{array}$ & goat & $\begin{array}{l}\text { polyclonal, } F\left(a b^{\prime}\right)_{2} \text { fragment, } \\
\text { 1:500 }\end{array}$ \\
\hline $\begin{array}{l}\text { DyLight } 549 \text { goat anti- } \\
\text { chicken IgY (lgG) }\end{array}$ & chicken $\lg Y(\operatorname{lgG})(H+L)$ & $\begin{array}{l}\text { Jackson ImmunoResearch, } \\
\text { 103-505-155 }\end{array}$ & goat & polyclonal, 1:500 \\
\hline $\begin{array}{l}\text { DyLight } 649 \text { goat anti-rabbit } \\
\text { lgG }\end{array}$ & rabbit $\lg G(H+L)$ & $\begin{array}{l}\text { Jackson ImmunoResearch, } \\
111-495-144\end{array}$ & goat & polyclonal, 1:500 \\
\hline
\end{tabular}

Abbreviations: DIG, digoxigenin; KLH, keyhole limpet hemocyanin; Htt, huntingtin; Ago, Argonaute; CPEB, cytoplasmic polyadenylation element binding protein

\section{Confocal microscopy}

Confocal imaging was performed using an LSM 510 META confocal scanning laser system on an Axiovert $200 \mathrm{M}$ microscope (Carl Zeiss). The instrument settings are detailed in Table 3 . Images were acquired with a Plan-Apochromat $100 \times / 1.3$ oil-immersion objective lens, which can reduce the chromatic shift. Brightness and contrast of images were adjusted before export to Adobe Photoshop CS for further processing. Co-localization analysis was performed using the co-localization function in the LSM software. Punctate regions of fluorescence intensity are defined as focal areas of intensity greater than the average local background fluorescence plus two times the standard deviation. In Photoshop, puncta staining in neurons were counted manually in either 2D image or 3D projection image. Total events were obtained by multiplying the average number for each square by the number of squares. Percent co-localization was calculated by dividing the co-localization events by the total number of events. The following precautionary steps were taken to ensure accuracy. The results generated by the software were first compared with the original images to confirm the presence of colocalizing spots. Only a certain percentage (greater than
$30 \%)$ of overlap was recognized as co-localization spots. Too little overlap of two targets, which appeared as very small spots in merged images, was not regarded as colocalization. A large sample size (more than 1500 puncta) was also used to improve accuracy of the analysis.

\section{Seven-color segmentation}

Segmentation was performed using a modified version of the formerly described program [40]. The principle of this approach is in the classification of each pixel into one of seven colors (red, green, blue, yellow, magenta, cyan and white) by choosing the minimal angular deviation between the RGB vector of a given pixel and seven classically defined edge vectors. White was defined as $(255,255,255)$ in RGB color model. Briefly, background was subtracted from the image and color segmentation was performed using a program integrated in ImageJ platform. After segmentation, images in seven pseudo channels were changed to grayscale and assigned seven defined colors. Finally, the images were smoothed and processed in ImageJ to generate a final version of seven pseudo channels, each of which represents one target or co-localization of two or three targets.

Table 3 Parameters and settings used for confocal microscopy

\begin{tabular}{lllll}
\hline Fluorescent dye & Laser & Excitation wavelength $(\mathbf{n m})$ & Emission filter $(\mathbf{n m})$ & Detector \\
\hline Alexa 488 & Argon (max.12\%) & 488 & BP 505-530 & Normal \\
\hline Dylight 549, Cy3 & HeNe1 (max. 29\%) & 543 & BP 560-615 & Normal \\
\hline Dylight 649 & HeNe2 (max. 44\%) & 633 & $659-723$ & META \\
\hline
\end{tabular}




\section{$3 \mathrm{D}$ reconstruction}

\section{(a) 3D reconstruction with $L S M$ software}

The $3 \mathrm{D}$ projection and reconstruction were performed with Projection function in the 3D View menu. Projection method: maximum; rotation: along $y$-axis; total projections: 64 .

\section{(b) $3 D$ reconstruction with Image $J$}

ImageJ 1.42 http://rsb.info.nih.gov/ij/ was obtained from the National Institutes of Health. Stacks of images from optical sections were exported to ImageJ as serial images, processed, and saved as TIFF image sequence. $3 \mathrm{D}$ projections were performed using image sequence, and the movies generated were saved as uncompressed AVI files. The settings for 3D projection were: rotation angle increment: 10; opacity: 0; surface depth-cueing: $100 \%$; interior depth-cueing: $50 \%$; projection methods: brightest point; interpolate: selected. The slice spacing was calculated using the scale relationship of $\mathrm{x}$ - and $\mathrm{z}$ axis. For example, if a $90 \mu \mathrm{m} \times 90 \mu \mathrm{m}$ image has a size of $512 \times 512$ pixels and optical section interval is 0.5 $\mu \mathrm{m}$, the slice spacing is 2.84 pixels $(512 \times 0.5 / 90)$.

\section{(c) Compression of movie files}

Movie files were compressed with Virtual Dub (Version 1.9.0.0, http://www.virtualdub.org) and saved as AVI. Cinepak Codec by Radius was used for compression.

\section{BDNF-3'UTR reporter plasmids}

The MS2 binding sites of the bacteriophage MS2 protein were cloned downstream of the Renilla luciferase gene in pRL-TK vector (Promega). Full-length $(2.85 \mathrm{~kb})$, short $(0.35 \mathrm{~kb})$ or long $(2.5 \mathrm{~kb}) 3$ 'UTR sequence of the mouse BDNF gene was amplified by PCR of a genomic DNA clone (gift of Lino Tessarollo) and inserted downstream of the MS2 binding sites to generate the three BDNF-3'UTR reporter constructs.

\section{Transfection of primary neurons}

Rat cortical neurons were isolated and cultured as previously described [41]. Neurons were fixed with 4\% PFA in PBS for 20 minutes at room temperature. Rat cortical neurons of DIV5 were typically transfected with $1 \mu \mathrm{g}$ total plasmid DNA with $1 \mu \mathrm{l}$ of Lipofectamine 2000 (Invitrogen) in OptiMEM (Invitrogen) per 24 well as recommended by the manufacturer. Transfection of $0.5 \mu \mathrm{g}$ NLS-MS2-Venus [16] and $0.5 \mu \mathrm{g}$ of one of three BDNF 3'UTR constructs were used for visualization of BDNF mRNA in neurons. Before transfection, 50\% of culture medium was removed and later used to replace the medium after 1-hour incubation with the transfection mixture. Neurons were fixed and immunostained 18-24 hours after transfection. Htt was detected by incubating cells with mouse $\alpha$-Htt (Millipore), followed by Cy3-conjugated goat $\alpha$-mouse IgG (Jackson ImmunoResearch Laboratories).

\section{Live cell imaging}

For imaging of BDNF mRNA in live cells, $0.33 \mu \mathrm{g}$ of NLS-MS2-Venus, $0.33 \mu \mathrm{g}$ of a BDNF 3'UTR plasmid and $0.33 \mu \mathrm{g}$ mRFP-Htt480-17Q [9] were transfected per well in a 24-well plate. 18-24 hours after transfection, neurons were transferred to Lab-Tek 2-well chamber cover glass (Nalge Nunc International) for live cell imaging. Less laser power (3\% for Argon laser and $10 \%$ for HeNe1) was used to avoid photobleaching and toxicity. Frame time was 15 seconds and frame interval 5.0 seconds. Images were acquired with a Plan-Neofluar $40 \times / 1.3$ oil-immersion objective lens. The images were exported and a movie file generated by ImageJ.

Additional file 1: Co-trafficking of Htt with BDNF short 3'UTR in rat cortical neurons was imaged live over 610.2 seconds. BDNF 3'UTR mRNA (detected by NLS-MS2-Venus) is in green and RFP-Htt480$17 Q$ in red. Co-localization of $\mathrm{Htt}$ with BDNF $3^{\prime} \mathrm{UTR}$ is shown in yellow in the merged image.

Additional file 2: Simultaneous visualization of BDNF mRNA with $\mathrm{Htt}$ and mRNA-binding protein CPEB1 in vibratome sections of rat brain cortex. BDNF mRNA, Htt and CPEB1 are shown in red, green and blue, respectively. Reconstruction method: ImageJ; optical slice interval: $0.5 \mu \mathrm{m}$; stack size: $16.0 \mu \mathrm{m}$.

Additional file 3: High-resolution visualization of temporal and spatial relationship and interaction of BDNF mRNA with $\mathrm{Htt}$ and CPEB1 in vibratome sections of rat brain cortex. Htt, BDNF mRNA and CPEB1 are indicated with number 1, 2, 3, respectively. Co-localization of Htt/mRNA (yellow), mRNA/CPEB1 (magenta), Htt/CPEB1 (cyan) and $\mathrm{Htt} / \mathrm{mRNA} / \mathrm{CPEB} 1$ (white) are indicated with 4, 5, 6, 7, respectively.

\section{Acknowledgements}

This work was supported in part by the Hereditary Disease Foundation (NT), grants from the CHDI Foundation (NT, MVC), and a Shared Instrumentation Grant from the NIH (S10 RR017970). We thank Ramin Shiekhattar for $\alpha$-Ago2 antibody, David Wells for $\alpha$-CPEB1 antibody, Hiroko Bannai for the NLS-MS2Venus plasmid, Lino Tessarollo for genomic BDNF clone, Feng He for the segmentation program modification and Wayne Rasband for the ImageJ program.

\section{Author details}

Department of Microbiology, New York University School of Medicine, New York, NY 10016, USA. ${ }^{2}$ University of Trieste, BRAIN Centre for Neuroscience, Department of Life Sciences, Via Giorgieri, 10, 34127 Trieste, Italy. ${ }^{3}$ Molecular Neurobiology Program, Departments of Cell Biology; Physiology and Neuroscience; and Psychiatry, Kimmel Center at Skirball Institute of Biomolecular Medicine, New York University School of Medicine, New York, NY 10016, USA.

\section{Authors' contributions}

BM and NT conceived the study and designed the experiments, BM and BPC performed the experiments and evaluated the data, and GB and ET provided reagents. BM, ET, MVC and NT wrote the paper. All authors have read and approved the final manuscript.

\section{Competing interests}

The authors declare that they have no competing interests.

Received: 3 March 2010 Accepted: 27 May 2010 Published: 27 May 2010 


\section{References}

1. Landles C, Bates GP: Huntingtin and the molecular pathogenesis of Huntington's disease. Fourth in molecular medicine review series. EMBO Rep 2004, 5(10):958-963.

2. $\mathrm{Li} \mathrm{SH}, \mathrm{Li} \mathrm{XJ}$ : Huntingtin and its role in neuronal degeneration. Neuroscientist 2004, 10(5):467-475

3. Imarisio S, Carmichael J, Korolchuk V, Chen CW, Saiki S, Rose C, Krishna G, Davies JE, Ttofi E, Underwood BR, et al: Huntington's disease: from pathology and genetics to potential therapies. Biochem J 2008, 412(2):191-209.

4. Zuccato C, Cattaneo E: Brain-derived neurotrophic factor in neurodegenerative diseases. Nat Rev Neurol 2009, 5(6):311-322.

5. Gharami K, Xie Y, An JJ, Tonegawa S, Xu B: Brain-derived neurotrophic factor over-expression in the forebrain ameliorates Huntington's disease phenotypes in mice. J Neurochem 2008, 105(2):369-379.

6. Strand AD, Baquet ZC, Aragaki AK, Holmans P, Yang L, Cleren C, Beal MF, Jones L, Kooperberg C, Olson JM, et al: Expression profiling of Huntington's disease models suggests that brain-derived neurotrophic factor depletion plays a major role in striatal degeneration. $J$ Neurosci 2007, 27(43):11758-11768.

7. Gauthier LR, Charrin BC, Borrell-Pages M, Dompierre JP, Rangone $H$, Cordelieres FP, De Mey J, MacDonald ME, Lessmann V, Humbert S, et al: Huntingtin controls neurotrophic support and survival of neurons by enhancing BDNF vesicular transport along microtubules. Cell 2004, 118(1):127-138.

8. Zuccato C, Ciammola A, Rigamonti D, Leavitt BR, Goffredo D, Conti L, MacDonald ME, Friedlander RM, Silani V, Hayden MR, et al: Loss of huntingtin-mediated BDNF gene transcription in Huntington's disease. Science 2001, 293(5529):493-498.

9. Savas JN, Makusky A, Ottosen S, Baillat D, Then F, Krainc D, Shiekhattar R, Markey SP, Tanese N: Huntington's disease protein contributes to RNAmediated gene silencing through association with Argonaute and $\mathrm{P}$ bodies. Proc Natl Acad Sci USA 2008, 105(31):10820-10825.

10. Savas JN, Ma B, Deinhardt K, Culver BP, Restituito S, Wu L, Belasco JG, Chao MV, Tanese N: A role for huntington disease protein in dendritic RNA granules. J Biol Chem 2010, 285(17):13142-13153.

11. Tongiorgi E, Righi M, Cattaneo A: Activity-dependent dendritic targeting of BDNF and TrkB mRNAs in hippocampal neurons. J Neurosci 1997, 17(24):9492-9505.

12. Tongiorgi $E$, Baj G: Functions and mechanisms of BDNF mRNA trafficking. Novartis Found Symp 2008, 289:136-147, discussion 147-151, 193-135.

13. Chiaruttini C, Vicario A, Li Z, Baj G, Braiuca P, Wu Y, Lee FS, Gardossi L, Baraban JM, Tongiorgi E: Dendritic trafficking of BDNF mRNA is mediated by translin and blocked by the G196A (Val66Met) mutation. Proc Nat Acad Sci USA 2009, 106(38):16481-16486.

14. Mouland AJ, Mercier J, Luo M, Bernier L, DesGroseillers L, Cohen EA: The double-stranded RNA-binding protein Staufen is incorporated in human immunodeficiency virus type 1: evidence for a role in genomic RNA encapsidation. J Virol 2000, 74(12):5441-5451.

15. Carson $\mathrm{JH}$, Cui $\mathrm{H}$, Barbarese $\mathrm{E}$ : The balance of power in RNA trafficking. Curr Opin Neurobiol 2001, 11(5):558-563.

16. Bannai $H$, Fukatsu $K$, Mizutani $A$, Natsume $T$, lemura $S$, Ikegami $T$, Inoue $T$, Mikoshiba K: An RNA-interacting protein, SYNCRIP (heterogeneous nuclear ribonuclear protein Q1/NSAP1) is a component of mRNA granule transported with inositol 1,4,5-trisphosphate receptor type 1 mRNA in neuronal dendrites. J Biol Chem 2004, 279(51):53427-53434.

17. Timmusk T, Palm K, Metsis M, Reintam T, Paalme V, Saarma M, Persson H: Multiple promoters direct tissue-specific expression of the rat BDNF gene. Neuron 1993, 10(3):475-489.

18. An JJ, Gharami K, Liao GY, Woo NH, Lau AG, Vanevski F, Torre ER, Jones KR, Feng $Y$, Lu B, et al: Distinct role of long $3^{\prime}$ UTR BDNF mRNA in spine morphology and synaptic plasticity in hippocampal neurons. Cell 2008, 134(1):175-187.

19. Pinaud R, Mello CV, Velho TA, Wynne RD, Tremere LA: Detection of two mRNA species at single-cell resolution by double-fluorescence in situ hybridization. Nat Protoc 2008, 3(8):1370-1379.

20. Pattabiraman PP, Tropea D, Chiaruttini C, Tongiorgi E, Cattaneo A, Domenici L: Neuronal activity regulates the developmental expression and subcellular localization of cortical BDNF mRNA isoforms in vivo. $\mathrm{Mol}$ Cell Neurosci 2005, 28(3):556-570.

21. Chiaruttini $C$, Sonego $M$, Baj $G$, Simonato M, Tongiorgi E: BDNF mRNA splice variants display activity-dependent targeting to distinct hippocampal laminae. Mol Cell Neurosci 2008, 37(1):11-19.

22. Li SH, Gutekunst CA, Hersch SM, Li XJ: Interaction of huntingtin-associated protein with dynactin P150Glued. J Neurosci 1998, 18(4):1261-1269.

23. Caviston JP, Ross $J$, Antony SM, Tokito M, Holzbaur EL: Huntingtin facilitates dynein/dynactin-mediated vesicle transport. Proc Natl Acad Sci USA 2007, 104(24):10045-10050.

24. Colin E, Zala D, Liot G, Rangone H, Borrell-Pages M, Li XJ, Saudou F, Humbert S: Huntingtin phosphorylation acts as a molecular switch for anterograde/retrograde transport in neurons. Embo J 2008, 27(15):2124-2134

25. Adachi N, Kohara K, Tsumoto T: Difference in trafficking of brain-derived neurotrophic factor between axons and dendrites of cortical neurons, revealed by live-cell imaging. BMC Neurosci 2005, 6:42

26. Baquet ZC, Gorski JA, Jones KR: Early striatal dendrite deficits followed by neuron loss with advanced age in the absence of anterograde cortical brain-derived neurotrophic factor. J Neurosci 2004, 24(17):4250-4258.

27. Zuccato C, Cattaneo E: Role of brain-derived neurotrophic factor in Huntington's disease. Prog Neurobiol 2007, 81(5-6):294-330.

28. Nagahara AH, Merrill DA, Coppola G, Tsukada S, Schroeder BE, Shaked GM Wang L, Blesch A, Kim A, Conner JM, et al: Neuroprotective effects of brain-derived neurotrophic factor in rodent and primate models of Alzheimer's disease. Nat Med 2009, 15(3):331-337.

29. Tongiorgi E: Activity-dependent expression of brain-derived neurotrophic factor in dendrites: facts and open questions. Neurosci Res 2008, 61(4):335-346.

30. Liu QR, Lu L, Zhu XG, Gong JP, Shaham Y, Uhl GR: Rodent BDNF genes, novel promoters, novel splice variants, and regulation by cocaine. Brain Res 2006, 1067(1):1-12.

31. Pruunsild P, Kazantseva A, Aid T, Palm K, Timmusk T: Dissecting the human BDNF locus: bidirectional transcription, complex splicing, and multiple promoters. Genomics 2007, 90(3):397-406

32. Barbee SA, Estes PS, Cziko AM, Hillebrand J, Luedeman RA, Coller JM, Johnson N, Howlett IC, Geng C, Ueda R, et al: Staufen- and FMRPcontaining neuronal RNPs are structurally and functionally related to somatic P bodies. Neuron 2006, 52(6):997-1009.

33. Chen ZY, Jing D, Bath KG, leraci A, Khan T, Siao CJ, Herrera DG, Toth $M$ Yang C, McEwen BS, et al: Genetic variant BDNF (Val66Met) polymorphism alters anxiety-related behavior. Science 2006 314(5796):140-143.

34. Soliman F, Glatt CE, Bath KG, Levita L, Jones RM, Pattwell SS, Jing D, Tottenham N, Amso D, Somerville $\mathrm{LH}$, et al: A genetic variant BDNF polymorphism alters extinction learning in both mouse and human. Science 2010, 327(5967):863-866.

35. Moon IS, Cho SJ, Jin I, Walikonis R: A simple method for combined fluorescence in situ hybridization and immunocytochemistry. Mol Cells 2007, 24(1):76-82.

36. Muddashetty RS, Kelic S, Gross C, Xu M, Bassell GJ: Dysregulated metabotropic glutamate receptor-dependent translation of AMPA receptor and postsynaptic density-95 mRNAs at synapses in a mouse model of fragile $\times$ syndrome. J Neurosci 2007, 27(20):5338-5348.

37. Tongiorgi $E$, Righi $M$, Cattaneo A: A non-radioactive in situ hybridization method that does not require RNAse-free conditions. J Neurosci Methods 1998, 85(2):129-139.

38. Goldstein LS, Yang Z: Microtubule-based transport systems in neurons: the roles of kinesins and dyneins. Annu Rev Neurosci 2000, 23:39-71.

39. Hallett PJ, Collins TL, Standaert DG, Dunah AW: Biochemical fractionation of brain tissue for studies of receptor distribution and trafficking. Curr Protoc Neurosci 2008, Chapter 1(Unit 1):16.

40. Ma B, He F, Jablonska J, Winkelbach S, Lindenmaier W, Zeng AP, Dittmar KE: Six-color segmentation of multicolor images in the infection studies of Listeria monocytogenes. Microsc Res Tech 2007, 70(2):171-178.

41. Osten P, Srivastava S, Inman GJ, Vilim FS, Khatri L, Lee LM, States BA, Einheber S, Milner TA, Hanson PI, et al: The AMPA receptor GluR2 C 
terminus can mediate a reversible, ATP-dependent interaction with NSF and alpha- and beta-SNAPs. Neuron 1998, 21(1):99-110.

42. Sharp AH, Loev SJ, Schilling G, Li SH, Li XJ, Bao J, Wagster MV, Kotzuk JA, Steiner JP, Lo A, et al: Widespread expression of Huntington's disease gene (IT15) protein product. Neuron 1995, 14(5):1065-1074.

doi:10.1186/1750-1326-5-22

Cite this article as: Ma et al.: Localization of BDNF mRNA with the Huntington's disease protein in rat brain. Molecular Neurodegeneration 2010 5:22.

Submit your next manuscript to BioMed Central and take full advantage of:

- Convenient online submission

- Thorough peer review

- No space constraints or color figure charges

- Immediate publication on acceptance

- Inclusion in PubMed, CAS, Scopus and Google Scholar

- Research which is freely available for redistribution 